\title{
Risk of zidovudine-induced anemia on human immunodeficiency virus (HIV) infection patients with different $\mathrm{CD}_{4}$ cell counts
}

\author{
Anak Agung Ayu Niti Wedayani" ${ }^{1}$ Eti Nurwening Sholikhah'², Erna Kristin ${ }^{2}$, Erwin \\ AsthaTriyono $^{3}$ \\ ${ }^{1}$ Postgraduate Student of Basic Medical and Biomedical Sciences, Faculty of Medicine, \\ Universitas Gadjah Mada, Yogyakarta, Indonesia. \\ ${ }^{2}$ Department of Pharmacology and Therapy, Faculty of Medicine, Universitas Gadjah \\ Mada, Yogyakarta, Indonesia, \\ ${ }^{3}$ Infectious Diseases and Tropical Medicine, Dr. Soetomo General Hospital, Surabaya, \\ Indonesia.
}

DOI: http://dx.doi.org/10.19106/JMedSci004901201704

\section{ABSTRACT}

Anemia is the most common hematologic abnormality in patients with human immunodeficiency virus (HIV) infection. This abnormality is associated with HIV infection itself, HIV-related opportunities infections or drug use. Zidovudine (AZT) is the most common cause of anemia in HIV patients. Recent study showed anemia in HIV patients is also associated with $C D_{4}$ cell counts. Aim of this study was to evaluate the risk of anemia on HIV patients with different $C_{4}$ cell counts after AZT-based antiretroviral therapy (ART).This retrospective cohort study was conducted using medical record of HIV patients in Dr. Soetomo General Hospital, Surabaya. Subjects who fulfilled the inclusion and exclusion criteria were divided into two group i.e. HIV patients with $\mathrm{CD}_{4}$ cell counts $200-350 \mathrm{cell} / \mathrm{mm}^{3}$ and those with $C_{4}$ cell counts $\geq 350 \mathrm{cell} / \mathrm{mm}^{3}$. All available demographics, clinical and laboratory data of subjects before and after AZT-based ART were then recorded and evaluated. Ninety-seven HIV patients (50 male and 47 female) were involved in this study. The result showed that the anemia incidence significantly increased after AZT-based ART $(p<0.05)$, however no significantly different in anemia incidence, mean $\mathrm{Hb}$ level reduction and $\mathrm{Hb}$ level time reduction were observed between HIV patients with $C D_{4}$ cell counts $200-350$ cell $/ \mathrm{mm}^{3}$ and those with $C D_{4}$ cell counts $\geq 350 \mathrm{cell} / \mathrm{mm}^{3}(\mathrm{p}>0.05)$. Gender, age, weight and clinical stage were not associated with anemia incidence $(\mathrm{p}>0.05)$. In contrast, anemia incidence is associated with $\mathrm{Hb}$ level before AZT therapy $(p<0.05)$. In conclusion, the anemia incidence in HIV patients after AZT based ART is not associated with the level of $C D_{4}$ cell counts, however it is associated with $\mathrm{Hb}$ levels before AZT therapy.

\section{ABSTRAK}

Anemia adalah kelainan hematologi yang paling sering dijumpai pada pasien yang terinfeksi human immunodeficiency virus (HIV). Kelainan ini dikaitkan dengan infeksi HIV itu sendiri, infeksi oportunitis yang berkaitan dengan HIV dan penggunaan obat. Zidovudin 


\begin{abstract}
(AZT) adalah penyebab anemia tersering pada pasien HIV. Penelitian terkini menunjukkan anemia pada penderita HIV juga dikaitkan dengan kadar $\mathrm{CD}_{4}$ pasien. Penelitian ini bertujuan mengkaji risiko anemia pada pasien HIV dengan kadar $\mathrm{CD}_{4}$ yang berbeda setelah menerima pengobatan anti retrovirus berbasis AZT. Penelitian cohort retrospective ini menggunakan data rekam medik pasien HIV di RSUP Dr. Soetomo, Surabaya. Subjek yang memenuhi kriteria inklusi dan eksklusi dibagi menjadi dua kelompok yaitu pasien HIV dengan kadar $\mathrm{CD}_{4} 200-350 \mathrm{sel} / \mathrm{mm}^{3}$ dan pasien dengan kadar $\mathrm{CD}_{4}>350 \mathrm{sel} / \mathrm{mm}^{3}$. Semua data demografi, klinik dan laboratorium subjek yang ada sebelum dan sesudah pengobatan anti retrovirus berbasis AZT dicatat dan dievaluasi. Sebanyak 97 pasien terdiri dari 50 laki-laki dan 47 wanita diambil datanya dalam penelitian ini. Hasil penelitian menunjukkan kejadian anemia meningkat secara nyata setelah pengobatan AZT pada kedua kelompok $(\mathrm{p}<0,05)$. Namun demikian, kejadian anemia, rerata penurunan kadar $\mathrm{Hb}$, dan waktu penurunan kadar $\mathrm{Hb}$ tidak berbeda nyata pada pasien dengan kadar $\mathrm{CD}_{4} 200-350 \mathrm{sel} /$ $\mathrm{mm}^{3}$ dan pasien dengan kadar $\mathrm{CD}_{4}>350 \mathrm{sel} / \mathrm{mm}^{3}(\mathrm{p}>0,05)$. Jenis kelamin, umur dan berat badan tidak berkaitan dengan kejadian anemia $(p>0,05)$, akan tetapi kadar $\mathrm{Hb}$ sebelum pengobatan dengan AZT berkaitan nyata dengan kejadian anemia $(p<0,05)$. Dapat disimpulkan, kejadian anemia pada pasien HIV setelah pengobatan anti retrovirus berbasis AZT tidak berkaitan dengan kadar $\mathrm{CD}_{4}$ tetapi berkaitan dengan kadar $\mathrm{Hb}$ sebelum terapai AZT.
\end{abstract}

Key words: human immunodeficiency virus (HIV), anemia, zidovudine, $\mathrm{CD}_{4}$ cell counts, adverse drug event

\section{INTRODUCTION}

Anemia is the most common haematologic abnormality in patients with human immunodeficiency virus (HIV) infection. Anemia affects $18 \%$ of patients with asymptomatic HIV-seropositive, $50 \%$ of those with middle-stage HIV disease and $75 \%$ of those with late-stage HIV disease. ${ }^{1,2} \mathrm{An}$ obvious cause of anemia in patients with HIV infection is blood loss. Other than blood loss, the pathophysiology of HIV associated anemia may involve decreased red blood cell (RBC) production, increased $\mathrm{RBC}$ destruction and ineffective $\mathrm{RBC}$ production. ${ }^{1,3}$ Factors associated with anemia in HIV patients include HIV infection itself, HIV-related opportunities infections or as a consequence of drug used for HIV infection and associated condition. ${ }^{4,5}$

Several drugs that commonly cause anemia in HIV patients have been reported. ${ }^{1,4,5}$ Among these drugs, zidovudine (AZT) is probably the most common cause of anemia in HIV patients. Zidovudine, a nucleoside reverse transcriptase inhibitor (NRTI), is one of earliest antiretroviral drugs used as a combination in some of the highly active antiretroviral therapy (HAART) regimens to treat of HIV/AIDS. Moreover, AZT is the first drug which was approved by US FDA for use in HIV/AIDS. ${ }^{6}$ Its used, however, is associated with hematologic abnormalities especially anemia. This anemia is observed in most of the patients within 3-6 months of initiation of AZT therapy. Female patient has been found to be a risk factor for anemia in some studies. ${ }^{6-8}$

Another factor currently associated with anemia in HIV patients is $\mathrm{CD}_{4}$ cell counts. It was reported that $3.2 \%$ of asymptomatic HIVseropositive patients with $\mathrm{CD}_{4}$ cell counts greater than 700 cells $/ \mathrm{mm}^{3}$ were anemic, where as anemia was observed in $20.9 \%$ of those with $\mathrm{CD}_{4}$ cell counts less than 249 cells/ $\mathrm{mm}^{3} .{ }^{9}$ Furthermore, $\mathrm{CD}_{4}$ cell counts less than 
200 cells $/ \mathrm{mm}^{3}$ was reported as a risk factor associated with anemia in HIV patients. Anemia was observed in $91.4 \%$ of HIVseropositive patients with CD4 cell counts less than 200 cells $/ \mathrm{mm}^{3} .{ }^{8,10}$ This study was conducted to evaluate therisk of anemia in human immunodeficiency virus (HIV) infection patients with different $\mathrm{CD}_{4}$ cell counts after AZT therapy.

\section{MATERIALS AND METHODS}

\section{Research design and subjects}

This retrospective cohort study was conducted using data from medical record of HIV patients who attended at Dr. Soetomo General Hospital, Surabaya between January 2005 to August 2015. The subjects were selected with the inclusion criteria as follows HIV patients underwent AZT-based therapy, aged 21-50 years, having $\mathrm{CD}_{4}$ cell counts $\geq$ $200 \mathrm{cell} / \mathrm{mm}^{3}$ before AZT-based antiretrovirus therapy (ART), having hemoglobin $(\mathrm{Hb})$ level $\geq 10$ and body mass index (BMI) 19-25. The exclusion criteria were pregnant women, underwent cotrimoxazole therapy, suffered from tuberculosis and received oral anti tuberculosis drugs, suffered certain diseases causing anemia such as renal chronic diseases and worm infection. Written inform consent was obtained from patients. The protocol of the study was approved by the Medical and Health Research Ethics Committee, Faculty of Medicine, Universitas Gadjah Mada, Yogyakarta.

\section{Procedure}

Subjects who met the inclusion and exclusion criteria were divided into two groups. The first group was HIV patients with $\mathrm{CD}_{4}$ cell counts $200-350 \mathrm{cell} / \mathrm{mm}^{3}$, and the second group was HIV patients with
$\mathrm{CD}_{4}$ cell counts $\geq 350$ cell $/ \mathrm{mm}^{3}$. All available demographics (age, gender, body height and body weight), clinical (history of diseases and history of treatment) and laboratory (viral load counts, $\mathrm{CD}_{4}$ cell counts and $\mathrm{Hb}$ level) data of subjects before AZT-based ART were then recorded. After AZT-based ART for six months, clinical and laboratory data of both groups were monitored and recorded again. A number of additional factors that considered as potential confounders were recorded such as opportunistic infections, renal insufficiency were recorded and analyzed.

\section{Data analysis}

All recorded demographics, clinical and laboratory data were presented as mean \pm standard deviation (SD) or number and percentage. Univariate analysis was applied to evaluate the demographics, clinical and laboratory data. Bivariate analysis such as chi-square ort-test was applied to evaluate the mean $\mathrm{Hb}$ level reduction and $\mathrm{Hb}$ level time reduction between group. Multivariate analysis using analysis of variance (ANOVA) was applied to evaluate the relationship between confounding factors and dependent variable.p value less than 0.05 was considered statistically significant.

\section{RESULTS}

During the study period 97 HIV patients who underwent AZT based ART were included in this study. Of these included patients, 50 $(51.5 \%)$ were male and $47(48.5 \%)$ female. The age of patients ranged from 26 to 46 years old. Most of these included patients had body weight ranged from 40 to $60 \mathrm{~kg}$ and in stage III of HIV infection. Furthermore, most of these included patients suffered from HIV infection through heterosexual transmission. 
TABLE 1. HIV patient characteristics who underwent AZT based ART in Dr. Soetomo General Hospital, Surabaya between January 2008 and August 2015.

\begin{tabular}{|c|c|}
\hline Characteristics & n (\%) \\
\hline \multicolumn{2}{|l|}{ Gender } \\
\hline - Man & $50(51.5)$ \\
\hline - Woman & $47(48.5)$ \\
\hline \multicolumn{2}{|l|}{ Age (years) } \\
\hline - $>46$ & $18(18.6)$ \\
\hline • 46-26 & $68(70.1)$ \\
\hline$\bullet<26$ & $11(11.3)$ \\
\hline \multicolumn{2}{|l|}{ Education } \\
\hline - Elementary School & $11(11.3)$ \\
\hline - Secondary School & $23(23.7)$ \\
\hline - Senior High School & $46(47.4)$ \\
\hline - University & $17(17.5)$ \\
\hline \multicolumn{2}{|l|}{ Occupation } \\
\hline - Employees & $65(67.0)$ \\
\hline - Daily labor & $18(18.6)$ \\
\hline - Permanent employment & $23(23.7)$ \\
\hline - Private employment & $1(1.0)$ \\
\hline - Unemployment & $33(33.0)$ \\
\hline \multicolumn{2}{|l|}{ Clinical stage } \\
\hline$\cdot \mathrm{I}$ & $22(22.7)$ \\
\hline • II & $16(16.5)$ \\
\hline • III & $42(43.3)$ \\
\hline • IV & $17(17.5)$ \\
\hline \multicolumn{2}{|l|}{ Body Weights (kg) } \\
\hline - $<40$ & $7(7.2)$ \\
\hline - $40-60$ & $71(7.2)$ \\
\hline$\cdot>60$ & $19(9.6)$ \\
\hline \multicolumn{2}{|l|}{ Transmission } \\
\hline - Heterosexual & $51(52.6)$ \\
\hline - Homosexual & $18(18.6)$ \\
\hline - Heterosexual + homosexual & 18(18.6) \\
\hline - Drug ubuse & $1(1.0)$ \\
\hline - Transfusion & $2(2.1)$ \\
\hline - Heterosexual, + drug ubuse & $6(6.2)$ \\
\hline - Unknown & $2(2.1)$ \\
\hline
\end{tabular}

This result showed that the anemia incidence significantly increased after AZT based ART comparae to beforethose both in HIV patients with $\mathrm{CD}_{4}$ cell counts 200-350 cell $/ \mathrm{mm}^{3}$ and those $\geq 350 \mathrm{cell} / \mathrm{mm}^{3}$ (TABLE 2). However, it was not affected by the level of $\mathrm{CD}_{4}$ cell counts. The anemia incidence on patients with $\mathrm{CD}_{4}$ cell counts 200-350 cell/ $\mathrm{mm}^{3}$ was not significantly different compared to those with $\mathrm{CD}_{4}$ cell counts $>350$ cell $/ \mathrm{mm}^{3}$ (TABLE 3).

TABLE 2. Hemoglobin level of HIV patients before and after AZT based ART in CD4 cell counts $200-350$ cell $/ \mathrm{mm} 3$ and $>350$ cell/ mm3 in Dr. Soetomo General Hospital, Surabaya between January 2005 and August 2008

\begin{tabular}{lcccc}
\hline Hb level & $\begin{array}{c}\text { Before } \\
\text { AZT }\end{array}$ & $\begin{array}{c}\text { After } \\
\text { AZT }\end{array}$ & Total & p \\
\hline CD $_{4} 200-350$ & & & & \\
- Severe & 5 & 13 & 18 & \\
- Moderate & 2 & 23 & 25 & \\
- Mild & 5 & 11 & 16 & $<0.05$ \\
- Very mild & 17 & 14 & 31 & \\
- Normal & 32 & 0 & 32 & \\
\hline CD4> 350 & & & & \\
- Severe & 0 & 6 & 6 & \\
- Moderate & 4 & 12 & 16 & \\
- Mild & 4 & 9 & 13 & 0.001 \\
- Very mild & 7 & 9 & 16 & \\
- Normal & 21 & 0 & 21 & \\
\hline
\end{tabular}

chi-square with $\mathrm{p}<0.05$

The $\mathrm{CD}_{4}$ cell counts, gender, age, body weight and clinical stage were not associated with the anemia incidence in HIV patients after AZT based ART (TABLE 4). However, the anemia incidence in those patients was significantly associated with the level of $\mathrm{Hb}$ before AZT based ART $(\mathrm{p}<0.05)$. 
Wedayani et al., Risk of zidovudine-induced anemia on human immunodeficiency virus (HIV) infection patients with different $C D_{4}$ cell counts

TABLE 3. Hemoglobin level of HIV patients with different level of CD4 cell counts before and after AZT based ART in Dr. Soetomo General Hospital, Surabaya between January 2005 and August 2008

\begin{tabular}{|c|c|c|c|c|}
\hline \multirow[b]{2}{*}{ Hb level } & \multicolumn{2}{|c|}{$\mathrm{CD}_{4}$ cell counts $\left(\mathrm{cell} / \mathrm{mm}^{3}\right)$} & \multirow{2}{*}{$\begin{array}{c}\text { RR } \\
95 \% \text { CI }\end{array}$} & \multirow[b]{2}{*}{$\mathbf{p}$} \\
\hline & $\begin{array}{c}200-350 \\
n(\%)\end{array}$ & $\begin{array}{l}>350 \\
\text { n }(\%)\end{array}$ & & \\
\hline \multicolumn{5}{|c|}{$\mathrm{Hb}$ before $\mathrm{AZT}$} \\
\hline - Severe & 5 & 0 & $3.94(0.41-93.15)$ & \multirow{5}{*}{0.185} \\
\hline - Moderate & 2 & 4 & $0.33(0.04-2.38)$ & \\
\hline - Mild & 5 & 4 & $0.82(0.016-4.21)$ & \\
\hline - Very mild & 17 & 7 & $0.59(0.51-5.13)$ & \\
\hline - Normal & 32 & 21 & 1 & \\
\hline \multicolumn{5}{|l|}{$\mathrm{Hb}$ after $\mathrm{AZT}$} \\
\hline - Severe & 13 & 6 & $1.39(0.32-6.08)$ & \multirow{4}{*}{0.815} \\
\hline - Moderate & 23 & 12 & $1.23(0.36-4.21)$ & \\
\hline - Mild & 11 & 9 & $0.79(0.20-3.14)$ & \\
\hline - Very mild & 14 & 9 & 1 & \\
\hline
\end{tabular}

chi-square with $\mathrm{p}<0.05$

TABLE 4. The relationship of patients' predictors to anemia incidence in HIV patients after AZT based ART in Dr. Soetomo General Hospital, Surabaya between January 2008 and August 2015

\begin{tabular}{|c|c|c|c|c|}
\hline \multirow[b]{2}{*}{ Variable } & \multicolumn{2}{|c|}{ Hb level* } & \multirow[b]{2}{*}{$\mathrm{RR}(95 \% \mathrm{CI})$} & \multirow[b]{2}{*}{$\mathrm{p}^{* *}$} \\
\hline & $\begin{array}{c}\text { Anemia } \\
\text { n }(\%)\end{array}$ & $\begin{array}{c}\text { Normal } \\
\mathrm{n}(\%)\end{array}$ & & \\
\hline \multicolumn{5}{|l|}{$\mathrm{CD} 4\left(\mathrm{sel} / \mathrm{mm}^{3}\right)$} \\
\hline - $200-350$ & $43(70.5 \%)$ & $18(29.5 \%)$ & $0.919(0.369-2.291)$ & \multirow{2}{*}{0.523} \\
\hline - $>350$ & $26(72.2 \%)$ & $10(27.8 \%)$ & 1 & \\
\hline \multicolumn{5}{|l|}{ Gender } \\
\hline - Man & $35(70.0 \%)$ & $15(30.0 \%)$ & $0.892(0.370-2.151)$ & \multirow{2}{*}{0.488} \\
\hline - Woman & $34(72.3 \%)$ & $13(27.7 \%)$ & 1 & \\
\hline \multicolumn{5}{|l|}{ Age (years) } \\
\hline$\cdot>46$ & $15(83.3 \%)$ & $3(16.7 \%)$ & $1.88(0.22-16.14)$ & \multirow{3}{*}{0.423} \\
\hline - $46-26$ & $46(67.6 \%)$ & $22(32.4 \%)$ & $0.78(0.15-3.74)$ & \\
\hline$\bullet<26$ & $8(72.7 \%)$ & $3(27.3 \%)$ & 1 & \\
\hline \multicolumn{5}{|l|}{ Weight (kg) } \\
\hline$\bullet<40$ & $6(85.7 \%)$ & $1(14.3 \%)$ & $1.6(0.11-46.01)$ & \multirow{3}{*}{0.423} \\
\hline - $40-60$ & $48(67.6 \%)$ & $23(32.4 \%)$ & $0.56(0.14-2.08)$ & \\
\hline$\cdot>60$ & $15(78.9 \%)$ & $4(21.1 \%)$ & 1 & \\
\hline \multicolumn{5}{|l|}{ Clinical stage } \\
\hline - $3-4$ & $43(72.9 \%)$ & $16(27.1 \%)$ & $1.240(0.508-3.029)$ & \multirow{2}{*}{0.401} \\
\hline - $1-2$ & $26(68.4 \%)$ & $12(31.6 \%)$ & 1 & \\
\hline \multicolumn{5}{|c|}{ Hb before AZT (g/dL) } \\
\hline - Anemia & $45(80.4 \%)$ & $11(19.6 \%)$ & $2.898(1.171-7.169)$ & \multirow{2}{*}{0.017} \\
\hline - Normal & $24(58.5 \%)$ & $17(41.5 \%)$ & 1 & \\
\hline
\end{tabular}


No significant difference in mean reduction and time reduction of $\mathrm{Hb}$ level between HIV patients with $\mathrm{CD}_{4}$ cell counts of 200- 350 cells $/ \mathrm{mm}^{3}$ and those with $\mathrm{CD}_{4}$ cell counts $>350$ cells $/ \mathrm{mm}^{3}$ were observed in this study (TABLE 5 and 6 ).

TABLE 5. Mean Hb level reduction (mean \pm SD) before and after AZT based ART of HIV patients with different CD4 cell counts in Dr. Soetomo General Hospital between January 2008 and August 2015

\begin{tabular}{lllll}
\hline \multirow{2}{*}{ Hb’s level } & \multicolumn{2}{l}{$\mathrm{CD}_{4}$ cell counts } & Mean diff $(95 \% \mathrm{CI})$ & $\mathrm{p}$ \\
\cline { 2 - 5 } & $200-350(\mathrm{n}=61)$ & $>350(\mathrm{n}=36)$ & & 0.388 \\
Before & $11.34 \pm 1.82$ & $11.67 \pm 1.69$ & $-0.322(-1.061-0.416)$ & 0.568 \\
After & $8.14 \pm 2.16$ & $8.41 \pm 2.25$ & $-0.265(-1.180-0.651)$ & 0.899 \\
Mean reduction & $3.20 \pm 2.11$ & $3.26 \pm 2.24$ & $-0.058(-1.180-0.651)$ & \\
\hline
\end{tabular}

t-test with $\mathrm{p}<0.05$

TABLE 6. Time reduction of Hb level (days) after AZT based in HIV patients in Dr. Soetomo General Hospital, Surabaya between January 2008 and August 2015

\begin{tabular}{llll}
\hline $\mathrm{CD}_{4}$ cell counts & & $\begin{array}{l}\text { Mean diff } \\
(95 \% \mathrm{CI})\end{array}$ & $\mathrm{p}$ \\
\hline $200-350(\mathrm{n}=61)$ & $>350(\mathrm{n}=36)$ & $-3.467(-12.809-5.874)$ & 0.463 \\
\hline $34.03 \pm 23.01$ & $37 \pm 21.27$ & -127
\end{tabular}

t-test with $\mathrm{p}<0.05$

\section{DISCUSSION}

This study showed that the anemia incidence significantly increased after AZT based ART in HIV patients (TABLE 2).It is ndicated that AZT can induce anemia in HIV patients. Zidovudine treatment is associated with bone marrow suppression and an increased risk of developing anemia. ${ }^{1}$ This result is suported with the previous studies reported by some authors. Women's Interagency HIV Study (WIHS) reported the presence of anemia in $42.6 \%$ of HIV-infected women patients receiving AZT therapy compared with $34.3 \%$ of those not receiving AZT. ${ }^{3}$ Furthermore, Agarwal et al. ${ }^{11}$ reported a high incidence of AZT-induced anemia (42.7\%) in HIV-infected patients from eastern part of India. In contrast Semba et al. ${ }^{12}$ reported that, although the use of zidovudine was associated with an increased risk of anemia in the preHAART era (1993-1996), use of zidovudine during the HAART era (1996-2000) was not significantly associated with anemia.

The study also showed that the anemia incidence was not associated with the level of $\mathrm{CD}_{4}$ cell counts. The anemia incidence on patients with $\mathrm{CD}_{4}$ cell counts $200-350$ cell/ $\mathrm{mm}^{3}$ was not significantly different compared to those with $\mathrm{CD}_{4}$ cell counts $>350$ cell $/ \mathrm{mm}^{3}$ (TABLE 3). It indicated that anemia incidence in HIV patients is not affected by the level of $\mathrm{CD}_{4}$ cell counts. The association between $\mathrm{CD}_{4}$ cell counts and anemia incidince is not clear. Previous studies the decrease of $\mathrm{CD}_{4}$ cell counts was independently associated with the increase of anemia risk.Anemia affected $30 \%$ of HIV patients with $\mathrm{CD}_{4}$ cell counts $\geq 500 \mathrm{cell} / \mathrm{mm}^{3}$ and $63-95 \%$ of those with 
$\mathrm{CD}_{4}$ cell counts $<200$ cell $/ \mathrm{mm}^{3} .{ }^{8}$ In addition, anemia more frequent affected HIV patients with $\mathrm{CD}_{4}$ cell counts $<350 \mathrm{cell} / \mathrm{mm}^{3}{ }^{3}{ }^{13}$ In contrast, another study reported that there was no association between anemia incidence and $\mathrm{CD}_{4}$ cell counts. ${ }^{14}$ Similarly a study among pregnant HIV positive women reported that there was no significant association between $\mathrm{Hb}$ level and CD4 cell counts. ${ }^{15}$

Although gender, age, weight and clinical stage have reported as risk factor for anemia in HIV patients in previous studies, $1,3,4,16$ in the present study did not find as risk factor. However, the level of $\mathrm{Hb}$ before based ART has been found as risk factor in this study. The different in study designs, methodologies use including inclusion and exclusion criteria and cut-offs used to define anemia may contribute to these defferences.

\section{CONCLUSION}

In conclusion, there are no differences in the risk of anemia, a mean reduction of $\mathrm{Hb}$ level and time reduction of $\mathrm{Hb}$ level between HIV patients after AZT based ART with $\mathrm{CD}_{4}$ cell counts $200-350 \mathrm{cell} / \mathrm{mm}^{3}$ and those $\mathrm{CD}_{4}$ cell counts $>350$ cell $/ \mathrm{mm}^{3}$. The anemia incidence in HIV patients after AZT based ART is associated with the $\mathrm{Hb}$ levels before AZT therapy.

\section{ACKNOWLEDGEMENTS}

We would like to thanks Dr.dr. Erwin Astha Triyono Sp.PD, KPTI, FINASIM and all staff of Dr. Soetomo General Hospital who provided us an opportunity to join their team gave access to the medical record and use the research facilities.

\section{REFERENCES}

1. Volberding PA, Levine AM, Dieterich D, Mildvan D, Mitsuyasu R, Saag M. Anemia in
HIV infection: clinical impact and evidencebased management strategies. Clin Infect Dis 2004; 38: 1454 - 63. https://doi.org/10.1086/383031

2. Mlisana K, Auld SC, Grobler A,van Loggerenberg F, Williamson C, Iriogbe I. Anaemia inacute HIV-1subtype $\mathrm{C}$ infection. PLoS ONE 2008; 3: e1626. https://research on line.lshtm.ac.uk/8174/1/pone.0001626.pdf

3. Levine AM,Berhane K, Masri-LavineL, Sanchez M, Young M, Augenbraun M, et al. Prevalence and correlates of anemia in a large cohort of HIV-infected women:Women's Interagency HIV Study. J Acquir Immune Defic Syndr 2001; 26: 28-35.

https://doi.org/10.1097/00042560200101010-00004

https://doi.org/10.1097/00126334200101010-00004

4. Subbaraman R, Devaleenal B, Selvamuthu P, Yepthomi T, Solomon SS, Mayer KH, et al. Factors associated with anemia in HIVinfected Individuals in Southern India. Int J STD AIDS 2015; 20: 489-92. https://doi.org/10.1258/ijsa.2008.008370

5. Miedani M, Rezaei F, Maracy MR, Avijgan M, Tayeri K. Prevalence, severity, and related factors of anemia in HIV/AIDS patients.J Med Sci 2012; 17: 138-142

6. Sharma SK. Zidovudine-induced anemia in HIV/AIDS. Indian J Med Res 2010; 132: 359-61.

7. Phe T, Thai S, Veng C, Sok S, Lynen L, van Griensven J.Risk factors of treatment-limiting anemia after substitution of zidovudin for stavudin in HIV-infected adult patients on antiretrovirus treatment. PLoS ONE 2013; 8:1-7. http://doi.org/10. 1371/journal. pone. 0060206.

8. Masaisa F, Gahutu JB, Mukiibi J, Delanghe J, Philippe J. Anemia in human immunodeficiency virus-infected and uninfected women in Rwanda. Am J Trop 
Med Hyg2011; 84(3):456-60. http://dx.doi. org/ 10.4269/ajtmh.2011.10-0519. https://doi.org/10.4269/ajtmh.2011.10-0519

9. Kaslow RA, Phair JP, Friedman HB, Lyter D, Solomon RE, Dudley J, et al. Infection with the human immunodeficiency virus: Clinical manifestations and their relationship to immune deficiency. A report from the Multicenter AIDS Cohort Study. Ann Intern Med 1987; 107: 474-480. https://doi.org/10.7326/0003-4819-107-4474

10. Parinitha SS \& Kulkarni MH. Haematoloical changes in HIV infection with correlation to CD4 cell count. AMJ2012; 5(3):157-62.

11. Agarwal D, Chakravarty J, Chaube L, Rai M, Agrawal NR, Sundar S. High incidence of zidovudine induced anaemia in HIV infected patients in eastern India. Indian $\mathrm{J}$ Med Res2010; 132: 386-9.

12. Semba RD, Shah N, Klein RS,Mayer KH, Schuman P, Vlahov D, et al. Prevalen and cumulative incidence of and risk factors for anemia in a multicenter cohort study of human immunodeficiency virus-infected and -uninfected women. Clin Infect Dis 2002; 34:

260-6.

https://doi.org/10.1086/338151

13. Mihiretie H, Taye B, Tsegaye A. Magnitude of anemia and associted factors among pediatric HIV/AIDS patients attendeing Zewditu Memorial Hospital ART Clinic, Addis Ababa, Ethiopia.Anemia 2015; Articel ID 479329.6.http://dx.doi.org/ 10.1155/2015/479329.

14. Pennap GR \& Abubakar K. Prevalence of anemia among human immunodeficiency virus infected patients accessing healthcare in Federal Medical Center Keffi, Nigeria. Int J Trop Dis Health 2015; 10(3): 1-7. https://doi.org/10.9734/IJTDH/2015/19657

15. Moyle G. Anemia in perpons with HIV infection: prognostic marker and contributor to morbidity. AIDS Review 2002; 4:13-20.

16. Omoregie R, Omokaro EU, Palmer O, Ogefere HO, Egbeobauwaye A, Adegbe JE, Osakwe SI, Ihemeje V. Prevalence of anemia among HIV-infected patients in Benin City, Nigeria. Tanz J Health Res. 2009; 11(1): 1-4. https://doi.org/10.4314/thrb.v11i1.43242 